\title{
TITLE:
}

\section{Thallous Ion Dimer Center in Alkali Halide Crystals(Abstract_要旨)}

\author{
$\operatorname{AUTHOR}(\mathrm{S})$ : \\ Tsuboi, Taiju
}

\section{CITATION:}

Tsuboi, Taiju. Thallous Ion Dimer Center in Alkali Halide Crystals. 京都大 学, 1970, 理学博士

ISSUE DATE:

1970-11-24

URL:

http://hdl.handle.net/2433/213517

RIGHT: 


\section{【32】}

\section{氏 名}

学位の種類 学位記 番号 学位授与の日付 学位授与の要件 研究科・専攻 学位論文題目
坪井泰住

理学: 博 土

理 博 第 199 号

昭和 45 年 11 月 24 日

学 位規則第 5 条第 1 項該 当

理学研究科物理学第一尃攻

Thallous Ion Dimer Center in Alkali Halide Crystals

(アルカリハライド結晶に括けるタリウムイオン対中心）

論文調查委員教授中井祥夫教授富田和久教授端恒夫

\section{論 文内容 の 要 旨}

不純物イオンとしてT1+イオンを含むアルカリ八ライド結晶の光学的性質については, 多くの研究がな

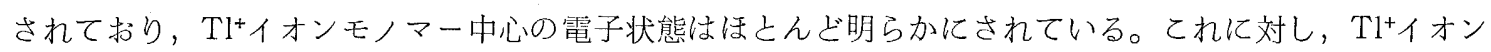

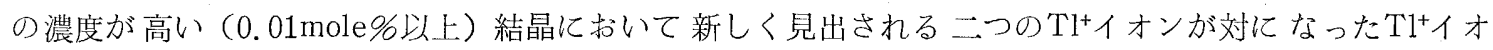
ンダイマー中心については，現在に到るまで余り詳しく調べられておらず，その性質についてす，確定し ていない点が多い。

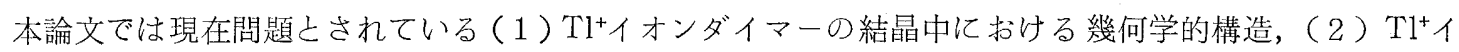
オンダイマー中心体の電子準位，および（3） Tl+イオンダイマーによる発光スペクトルを明らかにす るためにKI-Tl, $\mathrm{KBr}-\mathrm{Tl}, \mathrm{KCl}-\mathrm{Tl}$ および $\mathrm{KCl}-\mathrm{In} の$ 各結晶についてその吸収, 発光および励起スペクトルを

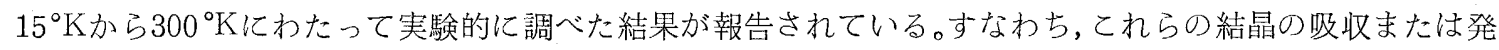
光スペクトルの浱度依存性を詳しく測定するととによって試料中に T1+イオンダイマーおよびIn+イオンダ イマーの存在するととを確認するととができた。KI-Tlにおいては，T1+イオンダイマー吸収帯がA帯の長 波長側に 2 本，C帯の長波長側に 3 本見出され，長波長側より $A_{1}, A_{2}, B_{1}, C_{1}$ おび $\mathrm{C}_{2}$ 帯乞名付けられた。 これらに相当する吸収带は KBr-Tlにおいてもすべて観測されたが，KCl-T1掞よび KCl-Inにおいては使 用した光学系の関係で，それぞれ $A_{2}, B_{1}, C_{1}$ 帯および $A_{1}, C_{1}$ 蒂のみが観測された。

次に，本論文では，得られたダイマーの吸収スペクトルを解析するために，ダイマーのエネルギー準位 図を求めるととが試みられている。まず，ダイマーを二つのモノマーが弱く結合している準分子と考え て，豊沢・井上によって与えられたモノマーの波動関数を用いて Heitler-London の方法により準分子 の波動関数を作り岕げた。ダイマーに対するハミルトニアンとしては，二つのモノマーに対するハミルト ニアンに，クーロンカで近似されるモノマー間の相互作用ハミルトニアンを加えたものを用いた。これら を用いて作られたエネルギー準位図からは，4本の吸収帯が予想され，そのうちの 2 本はA帯に他の 2 本 はC蒂に関係している。観測された $A_{1}$, および $\mathrm{A}_{2}$ 帯は，（1）それらが $\mathrm{A}$ 帯の近くに付隨しているとよ， 
（2）それらの吸収強度の比がエネルギー準位図から導かれる值に一致しているとと，および（3） $\mathrm{A}_{1}-\mathrm{A}_{2}$ 帯間のエネルギー間隔が $\mathrm{D}_{2 \mathbf{h}}$ 対称性をあつダイマーに対して導かれる值よよく一致することから，上述 のA帶に関係した2本のダイマー吸収帯であると同定した。さらに観測されたC らがC帯の近くに付随しているとと，(2） $A_{1}$ 帯とC $C_{1}$ 帯との強度比がエネルギー準位図より期待される值に 近いとと，および（3） $\mathrm{A}_{1}-\mathrm{A}_{2}$ 帯間と $\mathrm{C}_{1}-\mathrm{C}_{2}$ 帯間とのエネルギー間隔比がエネルギー準位図より期待される 值に近いことから，上述のC帯に関係した2本のダイマー吸収帯であると同定した。

このような同定は，KCl-InのIn+イオンダイマーの場合にも適用できる。観測された5本のダイマー吸 収帯のうちで残るB、帯については，(1) それがB帯の近くに付隨しているとと，(2) KI-Tl，KBr-T1およ びKCl-Tlに执いてB帯とB1带とのエネルギー間隔がほとんど同じであるとと，および（3）5本のダイマー 吸収帯のうちで一番強度が小さいことから，禁止帯であるB帯に関係したダイマ一吸収帯と考えられる が，その振動子強度の值がB帯のものに比べて約一桁大きいとととB帯と異なって，その強度が全く温度変 化しないととから，B帯に直接関係するダイマーの禁止帯に，エネルギー的に近いととろにある許容帯の C、帯が混ぜられるととによりB帯が誘起されていると推論した。

$\mathrm{Tl}^{+}$イオンダイマーの幾何学的構造に関しては，(1） $\mathrm{A}_{1}-\mathrm{A}_{2}$ 帯間のエネルギー間隔，(2） $\mathrm{A}_{1}$ 帯とA帯との 振動子強度の比拈よび (3) ハロゲンイオンを変えたKI-Tl, KBr-Tlおよび KCl-Tlのダイマーの吸収スペ クトルに执いて顕著な相違が見られなかったとよ，から $\mathrm{D}_{4 \mathrm{~h}}$ 対称性のダイマーのモデルより $\mathrm{D}_{2 \mathrm{~h}}$ 対称性の ダイマーのモデルの方がより確からしいとの結論を得ている。

\section{論文賽查の結果の要旨}

この論文は，不純物イオンとしてタリウムイオンを含む沃化力リウム，臭化カリウムおよび塩化カリウ ム結晶に扣けるタリウムイオンによる吸収书よび発光を詳しく測定し，それより得られた知見に基づいて タリウムイオンダイマーの電子状態拉よび幾何学的構造についての考察を試みている。さらに, タリウム イオンと同じ電子配置を有するインジウムイオンを不純物イオンとして含む塩化カリウム結晶についても 吸収抢よび発光を測定し，タリウムイオンダイマーに関する考察がインジウムイオンダイマーにも適用で きるか否かについての検討を行なっている。

申請者は, 吸収㧍よび発光スペクトルの濃度依存性から結晶中のダイマー中心の存在を確認し, 吸収书 よび励起スペクトルより5本のダイマー吸収帯を見出した。とのダイマー吸収帯を解析するために，二つ のモノマーイオンが弱く結合した準分子モデルを用いてダイマーに対するエネルギー準位図を作りあげ， それから導かれるスペクトルと観測されたスペクトルとを比較するととにより吸収帯の定量的な準位同定 を試みた。その結果，各種の sample について統一的な解釈を下すととに成功し，さらに，ての同定が インジゥムイオンダイマーにも適用できるととを明らかにした。

これらの結果は, 申請者に上る解析方法が一応満足なものであることを示している。また, ダイマ一吸

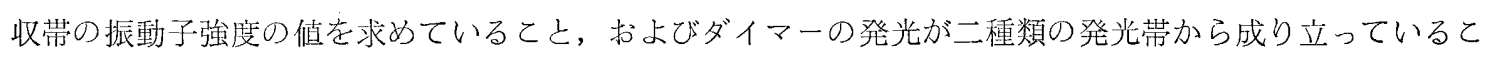
上を明らかにしたてとは，吸収および発光過程に㧍けるダイマーの電子状態の解明について重要な意義を 有するものである。 
ダイマーの結晶中における幾何学的構造に関しては，従来より偏光測定の結果から $\mathrm{D}_{2 \mathrm{~h}}$ 対称性のダイマ 一上， $\mathrm{D}_{4 \mathrm{~b}}$ 対称性のダイマーとの二つの異なったダイマーに対するモデルが提案されていたが，申請者は

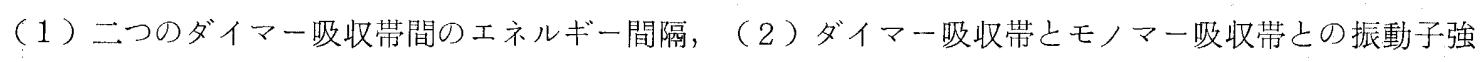
度の比拉よび（3）八ロゲンイオンを変えた沃化力リウム，奥化力リウム，塩化力リウム結晶におけるダ イマーの吸収スペクトルの類似性から $\mathrm{D}_{2 \mathrm{~h}}$ 対称性を持ったダイマーのモデルを支持した。ダイマーに関し て偏光測定法以外の方法によって，そのモデルに対する解析を提案したのは今回の論文がはじめてであ り，かつ，その結果は納得されるものである。

以上の上うに，ての研究は，不純物イオンダイマーの電子状態执よび幾何学的棈造を明らかにするとよ を試みたものであり，精密な測定技術を駆使することにより，乙れまで確定されていなかった点について 明確な結論を与えたととは，今後のとの分野での研究の発展の重要な緒となるものと考えられる。参考論 文で得られた絬果は，すべて主論文にあられた内容を指向する意味での予備的な内容と意義をすって打 り, 申請者が物性物理学の分野, 特に不純物中心に関する光物性の分野において広い知識よすぐれた研究 能力をむつことを示している。このように, 本論文は不純物中心の問題を通じ, 物性物理学の発展に寄与 するととろが少なくない。

よって，本論文は理学博士の学位論文として価值あるものと認める。 